\title{
ENVIRONMENTAL IMPACT OF USING GENERATORS IN THE UNIVERSITY OF TECHNOLOGY IN BAGHDAD, IRAQ
}

\author{
Wahab K. Ahmed ${ }^{1}$, Talib A. Abed ${ }^{2}$, Ahmed Q. Salam², Khalid S. Reza ${ }^{1}$, Maitham T. Mahdiy ${ }^{1}$, Miqdam \\ T. Chaichan ${ }^{1 *}$
}

\begin{abstract}
The environmental impact of using large electrical generators in the University of Technology in Iraq is studied. These generators are utilised due to the lack of electricity from the national grid. The emissions are very high and exceed the acceptable limits set by the United States Environmental Protection Agency, the World Health Organization and Iraqi Standard No. 4950. The impact of switching to the use of photovoltaic cell systems, as what is done in the Energy and Renewable Energies Technology Center (ERETC), and the environmental impact of this transformation are also studied.

Results show that when the generators are used, high concentrations of PM1, PM2.5 and PM10 are released, exposing students and staff to health hazards. The amounts of pollutants from $\mathrm{SO}_{2}, \mathrm{H}_{2} \mathrm{~S}$, NOx and volatile organic compounds are high due to the high sulphur content in Iraqi diesel fuel. Generator noise is extremely high that it could pose serious health risks to university staff and students. Furthermore, using the photovoltaic system considerably reduces PM1.0 and PM2.5 concentrations by $85.6 \%$ and $52.4 \%$, respectively. The levels of $\mathrm{CO}_{2}, \mathrm{CO}$, $\mathrm{H}_{2} \mathrm{~S}$ and $\mathrm{SO}_{2}$ decrease by $60.5 \%, 49.6 \%, 91.7 \%$ and $95.3 \%$, respectively. The noise inside ERETC is reduced by $29 \%$ compared with that in the external environment. Shifting towards the generation of photovoltaic electricity instead of using fossil fuel generators provides an immediate and appropriate treatment of Iraqi atmospheric pollution.
\end{abstract}

Keywords: Iraq, Air Quality, PM, Electricity Generators, Noise, University of Technology

\section{INTRODUCTION}

Iraq has been suffering from a severe shortage of electricity since the beginning of the international economic blockade in 1990. The number of hours of cutting the power supply in Baghdad and other provinces was increased after the US invasion in 2003. Moreover, many of the power plants are old, and installations have been sabotaged in the past few years; the suffering of Iraqis has increased because of the acute shortage of power supply [1].

The government's public electricity system produces $12,000 \mathrm{MW}$ of electricity at present. However, the country requires electricity of up to $20,000 \mathrm{MW}$, and such a need is increasing. These figures suggest a large deficit of up to $8 \mathrm{MW}$, and this shortage is due to the lack of proper planning and actual implementation of new projects $[2,3]$. The peak electricity generated is $8,000 \mathrm{MW}$ and could increase to $10,000 \mathrm{MW}$ under ideal conditions. Such production is reduced at the peak of summer to 6,000 or $7,000 \mathrm{MW}$, which covers only $50 \%$ of actual needs at best [4].

This significant shortage in national electricity production has led to the use of small generators (diesel or gasoline) in Iraqi homes; sometimes, large generators (diesel fuel) ranging from $150 \mathrm{kVA}$ to $500 \mathrm{kVA}$ are used for the operation of houses, facilities and factories $[5,6]$.

This lack of power production has forced the management of the University of Technology in Baghdad to deploy several large generators for handling its numerous colleges and departments when the power supply is cut off from the national network. These generators normally operate for two to four hours during official working days, and they are fuelled by Iraqi diesel fuel, which has high sulphur content (10,000 ppm to $25,000 \mathrm{ppm})$. The pollutants emitted from these generators exert a remarkable impact on the overall health of students and university staff [7].

This paper was recommended for publication in revised form by Regional Editor Hasan Köten

${ }^{1}$ Energy and Renewable Energies Technology Center, University of Technology, Baghdad, Iraq

${ }^{2}$ Environment Research Center, University of Technology, Baghdad, Iraq

*E-mail address: 11031@uotechnology.edu.iq, talibo1971@yahoo.com,20307@uotechnology.edu.iq, 140010@uotechnology.edu.iq,11491@uotechnology.edu.iq, 20185@uotechnology.edu.iq

Orcid id: 0000-0002-8521-0730, 0000-0002-8056-7060, 0000-0003-3365-0950, 0000-0001-9454-3564, 0000-0002-9242-4454, 0000-0002-8362-9132

Manuscript Received 01 May 2019, Accepted 27 August 2019 
Many epidemiological studies have shown that air pollution has negative effects on the human respiratory system $[8,9]$. Other studies have revealed that fossil-fuelled engines produce significant quantities of particulate matter (PM). The establishment of the European Emission Standards (Euro 5) has forced the car industry to reduce emitted PM by $80 \%$ [10]. Emitted gases are caused by combustion processes in the engine's combustion chambers. These emission types and rates differ remarkably and deteriorate air quality [11]. The PM emitted from internal combustion engines is a complex mixture of volatile soluble organic substances, sulphate, nitrate materials, atoms of soot carbon, ash and other compositions depending on the type of engine fuel (diesel or petrol), operating conditions, components and lubricating oil [12]. These pollutants exert a remarkable effect on air pollution, increase the greenhouse effect and enhance climate change [13].

Nitrogen dioxide $\left(\mathrm{NO}_{2}\right)$, nitrogen molecules and particles with mass smaller than $2.5 \mu \mathrm{m}$ (PM2.5) or 10 $\mu \mathrm{m}$ (PM10) are the most common markers of ambient air pollution. These pollutants are associated with many health endpoints in the long term [14]. Hence, these pollutants are monitored routinely throughout Europe and the United States [15].

Unburned or partially burnt hydrocarbons (known as volatile organic compounds or VOC) make up a wide range of complex organic chemicals formed mostly during the burning process or from hydrocarbons leaking from engines before entering the combustion chamber through the fuel system [14]. These materials are toxic, and with the presence of NOx the possibility of ozone and photochemical smog formation increase under the presence of solar radiation [16]. Ref. [17] revealed that the environment surrounding the University of Technology is highly polluted due to traffic on Mohammed Al-Qasem Highway. The study showed that a part of this pollution is caused by the excessive use of electrical generators to compensate for the lack of power in cut-off periods.

The pollutants produced by many generators emit highly toxic gases that affect the health of humans, animals and even plants. Several of these pollutants are considered carcinogens. These contaminants have been listed by the US Environmental Protection Organization Agency as priority pollutants [18, 19]. Many studies have proven the negative relationship between chronic noise exposure and human health $[20,21]$. These studies have reported that exposure to noise remarkably contributes to hearing loss, performance reduction and changes in physical and emotional reactions [22-24]. Most of the generators used in Iraq are old and do not have posttreatment equipment or sound silencers to purify their exhaust gas and emissions or reduce generator noise.

Given the catastrophic conditions experienced by Iraq that caused the deterioration of the country's infrastructure and important refineries, Iraqi diesel is one of the worst in the world; it has a sulphur content of $10,000 \mathrm{ppm}$ to $25,000 \mathrm{ppm}$. This sulphur is burned to form $\mathrm{H}_{2} \mathrm{~S}$ and $\mathrm{H}_{2} \mathrm{~S}$, both of which combine with the water vapour produced by fuel oxidation. This union produces sulphuric acids. The intensification of these acids in the parts of the equipment (cars, buses, generators, ships, etc.) exhaust system causes erosion and scratches in large parts of metal. Furthermore, such acids may cause ulceration and scratching in the respiratory system if they are inhaled by humans and animals [25]. Non-reactant sulphur molecules with oxygen or hydrogen form nuclei to collect carbon molecules that make up PM of all sizes (PM1.0, PM2.5, etc.) [26].

Many researchers have used several alternatives to reduce pollutants emitted by burning fossil fuels, whether diesel or gasoline, by adding many types of additives. Ref. [27] added hydrogen to diesel at different levels $(0,40$ and $75 \%)$, which was able to reduce $\mathrm{CO}, \mathrm{HC}$ and smoke pollutants clearly while NOx levels remained high. Ref. [28] added LPG and hydrogen to a diesel engine with different energy ratios and found a slight increase in thermal efficiency, $\mathrm{CO}$, and $\mathrm{HC}$ with a significant decrease in NOx levels. Ref. [29] added biofuel extracted from Chlorella algae to diesel and found a limited decrease in the brake thermal efficiency and a limited increase in fuel consumption. The additives caused $\mathrm{HC}$ and $\mathrm{CO}$ pollutants to drop by $28 \%$ and $22 \%$, respectively. NOx emissions increased up to $13 \%$. The researchers concluded that adding $20 \%$ of the algae biofuel to the diesel could be considered a suitable alternative to petro-diesel.

Photovoltaic (PV) cells have proven their global standing and are increasingly used in the global energy market [30]. This technique is environmentally friendly and does not produce any contaminant or noise. Furthermore, it works with available fuel that is clean and free because it is from sunlight. In Iraq, the outlook towards this kind of renewable energy remains sombre because Iraq is an oil country that can produce cheap electricity by using extensive resources of oil and natural gas. Iraqi decision makers and citizens view these cells as heavily affected by air conditions, such as solar radiation [31], temperature [32], relative humidity [33], wind speed [34] and dust [35]. The main hindrance to the widespread application of this type of energy is dust. Dust in Iraq is almost a daily phenomenon due to decades of drought, mismanagement of water resources and several continuous wars. 
Ref. [36] equipped an isolated island (Masirah Island in Oman) with electricity by using renewable energy sources instead of diesel generators. The researchers used the HOMER software to design and evaluate a hybrid solar/wind/diesel/battery system from many aspects (e.g. cost of the system and pollutants emitted by the system). The analysis results indicated that the cost of the proposed system is approximately $75 \%$ lower than that of the current operating system (diesel generators). By adopting the proposed system, greenhouse gas emissions can be reduced by approximately $25 \%$ compared with using diesel generators. The study concluded that the proposed system (solar/wind/diesel/battery hybrid system) is economically and practically suitable for application on Masirah Island.

Meanwhile, Ref. [37] built a $406 \mathrm{~kW}$ solar panel plant at Lahore University in Pakistan, which is currently facing a severe shortage of energy. The study concluded that the PV system is economically preferable and generates electrical energy without polluting the environment. Solar-generated power is less expensive for the unit compared with other energy types. The proposed system, assuming that it continues to produce $60 \%$ of its total power for seven working hours/day, is expected to recover its capital costs within 6.9 years due to the geographical location of the system, the surrounding environmental conditions and the quality of system manufacturing.

The University of Technology in Iraq conducted a pioneering experiment. It converted the Energy and Renewable Energy Technology Center (ERETC) to use solar energy for water heating with solar heaters. A total of $3.5 \mathrm{~kW}$ of PV electricity was produced, and it addressed all of the electricity needs of the centre, except for airconditioning which depended on the national grid.

The present study aims to measure and evaluate the pollutants emitted by the large generators used in the University of Technology in Baghdad, Iraq. The study investigated the extent of damage on the health of the university students and employees. Moreover, the study determined the environmental impact of using PV systems to generate electricity instead of diesel generators. The University of Technology can be considered a part of the Baghdadi community and can be a sample of the environmental hazard of Baghdad City. The difference between this study and others is that this work checked the air quality in a specific area and developed practical solutions to mitigate the issue.

\section{EXPERIMENTAL SETUP}

Given the lack electricity and multiple hours of power cuts, the University of Technology administration has deployed many generators (58) of multiple types and capacities to ensure the comfort of the educational environment and the success of the teaching process in classrooms, laboratories, offices, administration offices and other areas. Figure 1 presents a picture of the University of Technology from Google Earth, with focus on the operating generators' sites. Figure 1 illustrates the difficulty of verifying all of the generators, but in general, soot with a large molecular weight is deposited immediately near the generator exhaust. The rest of the lighter pollutants volatilise into air and sometimes move away for large distances depending on the air velocity. January, March and June in 2018 were selected to represent winter, spring and summer. The pollutants in these months were measured in the atmosphere surrounding the ERETC from four dimensions, namely, 25, 17.5, 10 and $5 \mathrm{~m}$, and from the four sides of the building. The concentrations of the same pollutants were also measured in the centre's rooms and laboratories for comparison. The measurements were conducted 20 days per month, and the average was used in plotting the curves.

Several devices were used to measure pollutants, such as PM1, PM2.5, PM7, PM10 and total suspended particulate (TSP). The emitted NOx, VOC, $\mathrm{H} 2 \mathrm{~S}$ and $\mathrm{SO} 2$ in addition to noise were determined. Table 1 lists the names, specifications and uncertainties of the measuring devices. All devices were calibrated at the Central Organization for Standardization and Quality Control-Iraq.

Table 1. Measuring instruments' specifications

\begin{tabular}{|l|l|l|l|l|c|}
\hline No. & Device name & The measured pollutant & Made in & Range & Uncertainty \\
\hline 1 & G460 & $\mathrm{CO}, \mathrm{CO}_{2}, \mathrm{H}_{2} \mathrm{~S}, \mathrm{NOx}, \mathrm{SO}_{2}, \mathrm{O}_{3}$ & Germany & $0-55 \mathrm{ppm}$ & 0.14 \\
\hline 2 & G460 & Ozone, VOC & Germany & $0-500 \mathrm{ppm}$ & 0.12 \\
\hline 3 & AEROCET & PM1, PM2.5, PM7, PM10, TSP & USA & $5-250 \mathrm{ppm}$ & 0.2 \\
\hline 4 & Sound level meter & Sound level & Japan & $0-120 \mathrm{~dB}$ & 0.23 \\
\hline
\end{tabular}




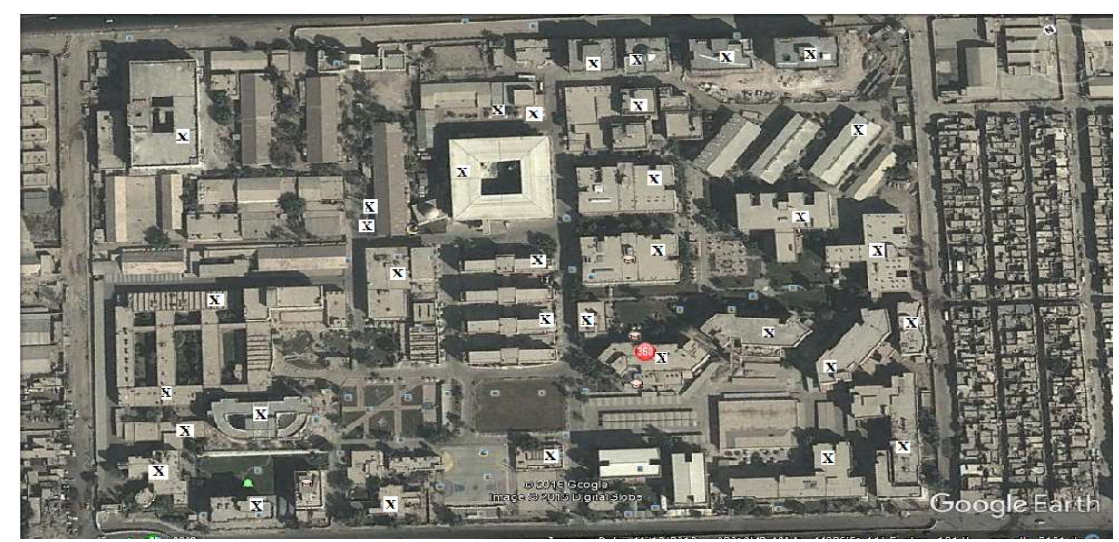

Figure 1. University of Technology from the air illustrating the location of operating generators

As a pilot experiment and the first of its kind in Iraq, ERETC has been equipped with solar panels (33 modules) supplying $3.5 \mathrm{~kW}$ of power with the installation of six solar water heaters to provide the centre with hot water. Table 2 shows the specifications of the solar water heaters and PV cells used.

Table 2. Specification of the used solar water heaters and PV panels

\begin{tabular}{|l|c|}
\hline \multicolumn{2}{|c|}{ Solar water heaters } \\
\hline Manufacturer & General Company of Electrical Manufactures-IRAQ \\
\hline Collector capacity & 120 liters \\
\hline Collector dimensions & Diameter: 450 mm; length: 1500 mm \\
\hline Pipes number & 20 pipes \\
\hline Pipes diameter & 2 inches \\
\hline \multicolumn{2}{|c|}{ Photovoltaic panels } \\
\hline Panel's weight & $11.4 \mathrm{~kg}$ \\
\hline Panel's dimensions & 1450 X 720 X 35 mm \\
\hline Peak power & $110 \mathrm{~W}$ \\
\hline Open circuit voltage & $21.6 \mathrm{~V}$ \\
\hline Short-circuit current & $7.0 \mathrm{~A}$ \\
\hline Maximum power voltage & $17.2 \mathrm{~V}$ \\
\hline Maximum power current & $6.40 \mathrm{~A}$ \\
\hline
\end{tabular}

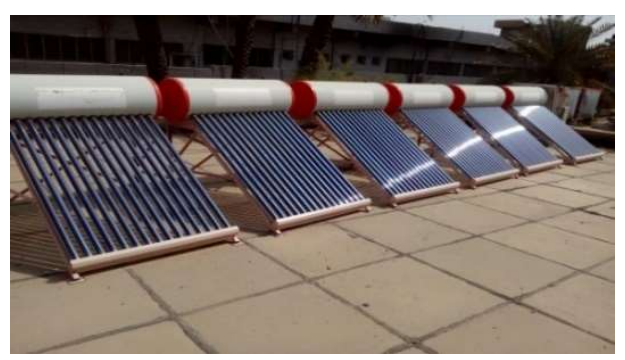

Figure 2. Solar water heater system for ERETC

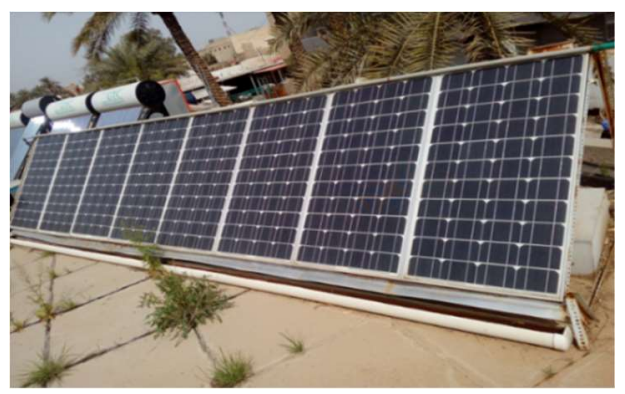

Figure 3. Part of the PV system used in ERETC 
The PV system is connected to the grid to supply surplus power to it. It is also connected to a set of batteries to equip the centre with electrical power on cloudy and dusty days. The system operates from 8:00 AM to 3:30 PM on official working days. Electricity is supplied to all electrical devices, such as computers, photocopying machines, laboratory equipment and lighting fixtures. The system does not provide electricity to airconditioning equipment. Figure 2 shows the solar water heaters used in the centre, and Figure 3 presents the PV system used in the centre.

\section{Test procedure}

Variable pollutant concentrations (PM1.0, PM2.5, PM7.0, PM10, TSP, $\mathrm{CO}, \mathrm{CO}_{2}, \mathrm{NOx}, \mathrm{VOC}, \mathrm{SO}_{2}, \mathrm{H}_{2} \mathrm{~S}$ and noise) were measured in the area around the centre and inside its rooms and laboratories. The mean of the three months was calculated and compared. The measuring devices were placed at a height of $1.5 \mathrm{~m}$ from the ground surface. The pollutants above the roof of ERETC were also measured and considered. External measurements were obtained at different distances $(5,10,17.5$ and $25 \mathrm{~m})$ from the outer wall of the centre in the outdoor environment. Internal measurements were performed in the centre of each room, and daily and monthly average readings were recorded.

\section{RESULTS AND DISCUSSIONS}

Figure 1 shows that the University of Technology uses 58 generators, which vary in type and rated power. These generators are used simultaneously when the grid power is cut. A variation in the generators' rated power increases the difficulty of repair and maintenance. Poor maintenance and repair result in high pollutant levels.

PM pose a major threat to health. These particles are divided into several varieties based on particle diameter. Figure 4 presents the average concentrations of the measured PM outside and inside ERETC for three months. The generators emit high levels of PM1 and PM2.5, which are ultra-fine particles and the most dangerous amongst all PM types. Increased PM emission results from combustion degradation, whereas reduced PM emission denotes satisfactory burning characteristics. The figure indicates that the PM level increased from when the measuring process began to approximately 1.30 hours of operation; afterwards, it decreased. This result reveals the effect of the engine worming process of the large-weight generators. The air inside ERETC is cleaner than the air outside because PM1.0 levels are reduced by $85.6 \%$ and PM2.5 levels are reduced by $52.4 \%$. The generators' engines emit exhaust gases in the atmosphere, and the pollutants rise into the air and move large distances from the source. However, in this case, the emitted exhaust gases move to other sections of the university or to the residential areas and shops surrounding the university. Notably, the effect of the generators that supply power to the surrounding areas of the university was not considered in this work. Nevertheless, its exhaust gases certainly affect the quality of air in the university according to the air movement and direction. The use of the PV system provides a clear reduction in the concentrations of the two dangerous pollutants.

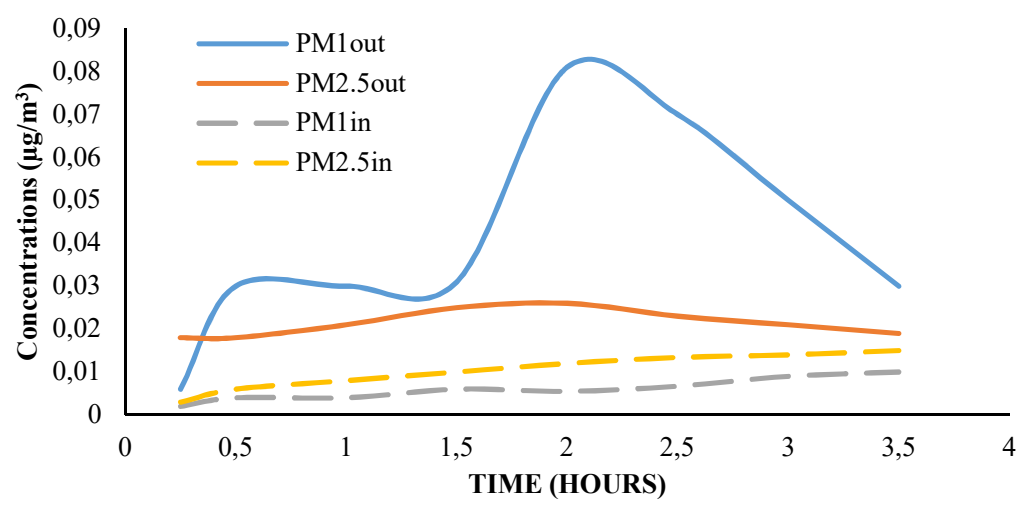

Figure 4. Average measured PM1 and PM2.5 levels emitted during the test period

Figure 5 shows the concentrations of heavy PM (PM7, PM10 and TSP) during the test period. The figure shows that the levels of these pollutants increase considerably after an hour of operation then stabilise at low levels for the rest of the operating period relative to the air surrounding the centre. The air within the centre has low concentrations of these materials, indicating the improvement in indoor air quality generated by adding and 
equipping the centre with PV electricity. The percentage of these pollutants inside the centre's air relatively increases by keeping the generators working after two hours. This result indicates that the quality of air, whether internal or external, decreases due to the continuous operation of the generators for more than two hours. The total average TSP measured (representing the total emitted particles) exceeded the acceptable levels in EPA (300 ppm) for the four-hour operation, which is half of the specified period by EPA.

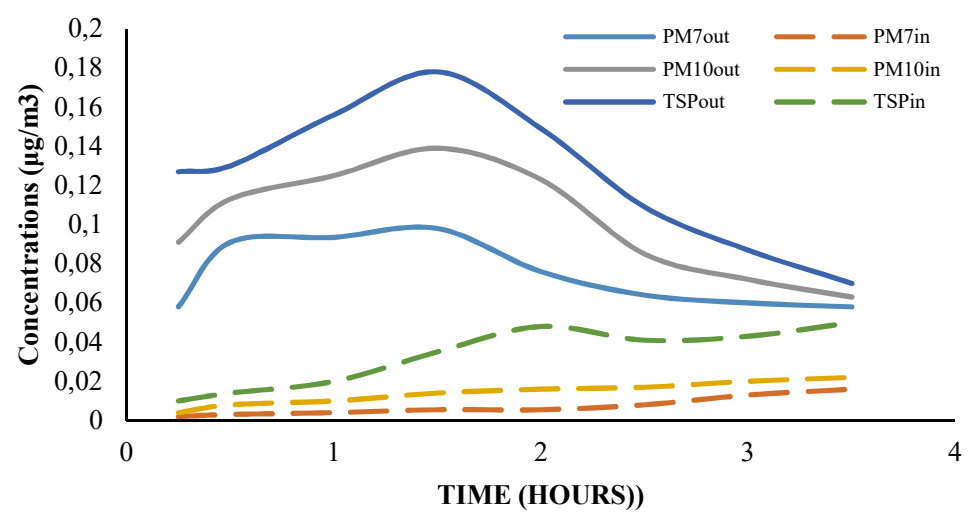

Figure 5. Average measured PM7, PM10 and TSP levels emitted during the test period

Figure 6 shows the average concentrations of $\mathrm{CO}$ and $\mathrm{CO}_{2}$ in the air inside and outside of ERETC for the studied period. The $\mathrm{CO}$ levels in outer air were high and posed remarkable health risks, especially because this gas is a poisonous pollutant. In general, $\mathrm{CO}_{2}$ concentrations were higher than $\mathrm{CO}$ concentrations because $\mathrm{CO}_{2}$ is the main gas resulting from the combustion process with $\mathrm{H}_{2} \mathrm{O}$. The high $\mathrm{CO}$ levels indicate that the university generator engines require serious maintenance and exhaust gas treatments. These pollutants' levels decreased significantly inside ERETC, indicating good air quality. The results show that using the photoelectric system has improved the quality of air inside the centre. Such an improvement is reflected in the health of the residents and their comfort. Comparisons of the concentrations of $\mathrm{CO}_{2}$ and $\mathrm{CO}$ showed that the decrement rates during the test period were $60.5 \%$ and $49.6 \%$ for the benefit of air inside the centre.

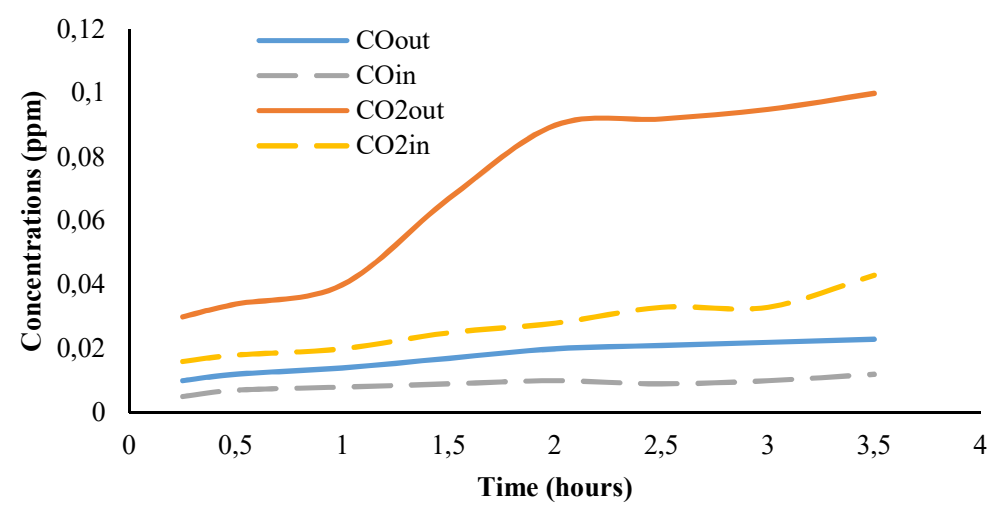

Figure 6. Average emitted $\mathrm{CO}$ and $\mathrm{CO}_{2}$ emission concentration during the test period

Figure 7 indicates the sulphur pollutants $\left(\mathrm{SO}_{2}\right.$ and $\left.\mathrm{H}_{2} \mathrm{~S}\right)$ measured inside and outside ERETC. The levels of these pollutants were high outside ERETC. Iraqi diesel fuel is characterised by high sulphur content exceeding $10,000 \mathrm{ppm}$ ( $1 \%$ mass content) [38]. The reaction between $\mathrm{H}_{2}$ and sulphur to produce $\mathrm{H}_{2} \mathrm{~S}$ means a part of the reactive hydrogen is lost to produce pollutants instead of producing power and $\mathrm{H}_{2} \mathrm{O}$. In the same manner, reaction oxidation of sulphur means a part of the oxidiser is spent on producing dangerous $\mathrm{SO}_{2}$. This emission can react with $\mathrm{H}_{2} \mathrm{O}$ to result in sulphuric acid that can cause corrosion of engine parts, and if it settles on the ground, then it could affect the groundwater and soil. Operation of the tested generators for more than two hours caused a large increase in the emitted pollutants. However, we found low concentrations of these pollutants inside the centre. 
Comparison of these pollutant levels showed that $91.7 \%$ and $95.3 \%$ reductions in concentrations were observed for $\mathrm{H}_{2} \mathrm{~S}$ and $\mathrm{SO}_{2}$, respectively, when the PV system was used.

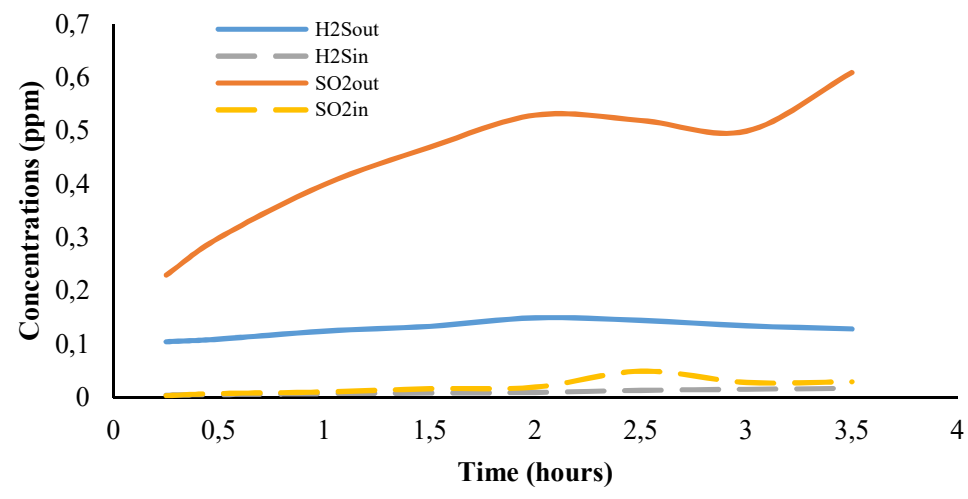

Figure 7. Sulphur pollutant average concentrations for the test period

Figure 8 demonstrates NOx and VOC concentrations for the studied period inside and outside ERETC. The NOx levels increased with time due to the increase in combustion chamber temperature. The World Health Organization (WHO) has restricted the one-hour exposure limit not to exceed $0.021 \mathrm{ppm}$. In this study, the measured concentration in one hour was $0.113 \mathrm{ppm}$, which represents the risks associated with the burning of high-sulphur fuel. Ref. [39] revealed that the sulphur contents in Iraqi diesel fuel reduce the cetane number and cause low power and high fuel consumption, in addition to high pollutant levels.

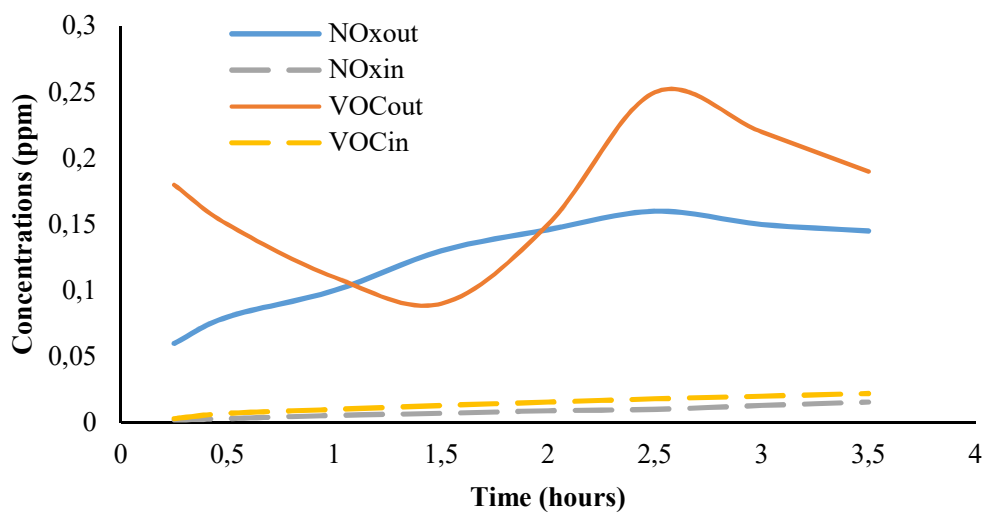

Figure 8. NOx and VOC concentrations for the studied generators

VOC pollutants, which are as risky as NOx, were emitted at high levels that exceeded the NOx ones. These emissions indicate the poor maintenance of the engines under study and the need for post-treatment for exhaust gases. The use of the PV system enhanced the air quality inside the centre and reduced NOx and VOC levels by $93.3 \%$ and $94 \%$, respectively. These significant reduction rates were managed by using a solar PV system.

Figure 9 shows the measured noise intensity inside and outside ERETC for the studied period. The noise outside ERETC was high and exceeded $60 \mathrm{~dB}$ during most of the measuring period. These noise levels exert a negative effect on the comfort of the staff and students of the university. Competent authorities in the university must equip these generators with effective and appropriate noise dampers to create a high-quality academic environment. The noise levels inside ERETC were lower than $50 \mathrm{~dB}$ throughout the test period. The lack of running generators adjacent to the centre, as is the case for the rest of the departments and colleges of the university, reduced the noise inside the centre during the test period by $29.2 \%$.

Table 3 compares the accepted EPA, WHO and Iraqi pollutant limits and the recent study's measurements outside ERETC. The table reveals high concentrations of the studied pollutants emitted by the university's generators. Poor maintenance and the type of diesel fuel (which is one of the worst worldwide) caused this result. 
The Central Bureau of Quality Control and Measurements has established an Iraqi specification (standard no. 4095) for reducing pollutants from diesel engines. Comparison of the resulting pollutants and this standard indicated that the emitted pollutants exceed permissible limits. Good and periodic maintenance is necessary to reduce these pollutants. Moreover, improved diesel fuel or other alternatives with reduced sulphur content must be used.

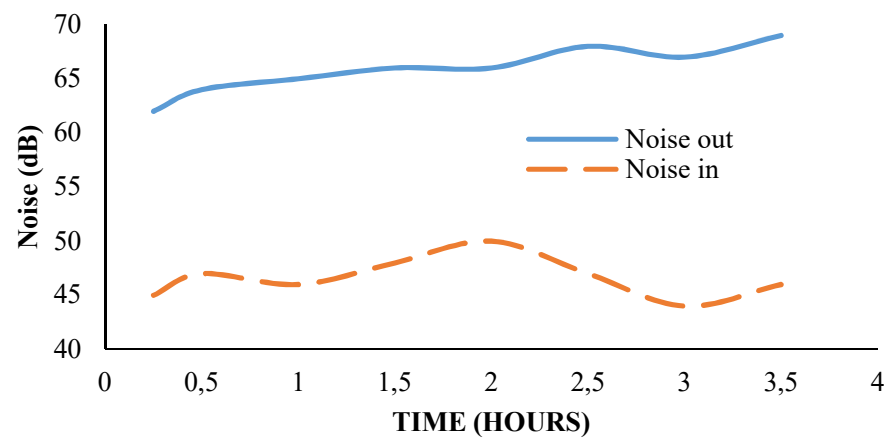

Figure 9. Average emitted noise from the tested generators

Table 3. Comparison of the accepted EPA, WHO and Iraqi pollutant limits and the recent study's measurements

\begin{tabular}{|c|c|c|c|c|c|c|}
\hline \multirow{2}{*}{ No. } & \multirow{2}{*}{ The pollutant } & \multirow{2}{*}{$\begin{array}{c}\text { Exposure time } \\
\text { (h) }\end{array}$} & \multicolumn{4}{|c|}{ Concentrations } \\
\cline { 3 - 7 } & & & EPA & WHO & $\begin{array}{c}\text { Iraqi } \\
\text { Standard }\end{array}$ & $\begin{array}{c}\text { Recent } \\
\text { study }\end{array}$ \\
\hline \multirow{2}{*}{1} & \multirow{2}{*}{$\mathrm{CO}$} & 8 & 0.09 & 0.011 & 0.035 & 0.23 \\
\cline { 3 - 7 } & & 1 & 20 & - & 15 & 17.34 \\
\hline \multirow{2}{*}{2} & \multirow{2}{*}{$\mathrm{SO}_{2}$} & 24 & 0.04 & 0.06 & 0.05 & 0.61 \\
\cline { 3 - 7 } & & 1 & 0.25 & 0.75 & 0.60 & 0.445 \\
\hline \multirow{2}{*}{3} & $\mathrm{NO}_{2}$ & 24 & 0.099 & - & 0.067 & 0.15 \\
\cline { 3 - 7 } & \multirow{2}{*}{4} & 1 & 0.018 & 0.021 & 0.021 & 0.1213 \\
\cline { 3 - 7 } & \multirow{2}{*}{$\mathrm{VOC}$} & 8 & 0.080 & 0.060 & 0.057 & 0.25 \\
\cline { 3 - 7 } & & 1 & 0.09 & - & .088 & 0.167 \\
\hline
\end{tabular}

\section{CONCLUSIONS}

Air quality was investigated by measuring emissions emitted by generators working inside the University of Technology in Iraq. The measuring period was conducted during the generators' operation for three selected months in 2018 (January, March and June). Air pollutants (PM1, PM2.5, PM7, PM10, TSP, NOx, VOC, SO2, $\mathrm{H} 2 \mathrm{~S}$ and noise) were measured and recorded on many days, and the average of the results was determined and evaluated. The results revealed high concentrations of all the tested pollutants outside ERETC, whereas the levels were low and within the acceptable air quality ranges inside the centre. Compared with the air quality outside ERETC, the air quality inside the centre showed significant reductions of $85.6 \%$ and $52.4 \%$ in PM1.0 and PM2.5, respectively. The $\mathrm{CO}_{2}, \mathrm{CO}, \mathrm{H}_{2} \mathrm{~S}$ and $\mathrm{SO}_{2}$ levels decreased by $60.5 \%, 49.6 \%, 91.7 \%$ and $95.3 \%$, respectively. Furthermore, the noise inside ERETC was reduced by $29 \%$ compared with that in the external environment.

\section{NOMENCLATURE}

$\mathrm{CO} \quad$ Carbon monoxide

$\mathrm{CO}_{2} \quad$ Carbon dioxide

dP Decibel

ERETC Energy and Renewable Energies Technology Center

$\mathrm{H}_{2} \mathrm{~S} \quad$ Hydrogen sulfide

$\mathrm{NO}_{2} \quad$ Nitrogen oxide

NOx Nitrogen oxides

PM Particulate matter

ppm Part per million

$\mathrm{SO}_{2} \quad$ Sulphur oxide

SOx Sulphur oxides

TSP Total suspended particulates

WHO World Health Organization

VOC Voltaic organic compounds 


\section{REFERENCES}

[1] Kazem HA, Chaichan MT. Status and future prospects of renewable energy in Iraq. Renewable and Sustainable Energy Reviews 2012; 16(1): 6007-6012. https://doi.org/10.1016/j.rser.2012.03.058.

[2] Brinckerhoff P. Master plan for the KRG Electricity Sector. Parsons Brinckerhoff, Erbil, Iraq, 2009a.

[3] Brinckerhoff P. Final report on the survey of private generation in the Baghdad Governorate. Parsons Brinckerhoff, Baghdad, 2009b.

[4] UN Inter-Agency Information and Analysis Unit. Landmines and unexploded ordnances factsheet in Iraq. United Nations, New York, 2012.

[5] Al-Waeely AA, Salman SD, Abdol-Reza WK, Chaichan MT, Kazem HA and Al-Jibori HSS, Evaluation of the spatial distribution of shared electrical generators and their environmental effects at Al-Sader CityBaghdad-Iraq. International Journal of Engineering \& Technology IJET-IJENS 2014; 14(2): 16-23.

[6] Chaichan MT, Kazem HA. Generating Electricity Using Photovoltaic Solar Plants in Iraq, Springer, ISBN: 978-3-319-75030-9, 2018. https://doi.org/10.1007/978-3-319-75031-6.

[7] Landrigan PJ, Fuller R, Fisher S, Suk WA, Sly P, Chiles TC, Bose-O'Reilly S. Pollution and children's health. Science of the Total Environment 2019; 650: 2389-2394. https://doi.org/10.1016/j.scitotenv.2018.09.375.

[8] Ducret-Stich RE, Delfino RJ, Tjoa T, Gemperli A, Ineichen A, Wu J, Phuleria HC and Liu LJS. Examining the representativeness of home outdoor PM2.5, EC, and OC estimates for daily personal exposures in Southern California. Air Qual Atmos Health 2012; 5: 335-351.

[9] Dhahad HA, Chaichan MT, Megaritis T. Performance, regulated and unregulated exhaust emission of a stationary compression ignition engine fueled by water-ULSD emulsion. Energy 2019; 181: 1036-1050. https://doi.org/10.1016/j.energy.2019.05.200.

[10] Gül MZ, Köten H, Yılmaz M, Savcı İH. Advanced numerical and experimental studies on ci engine emissions. Journal of Thermal Engineering 2018; 4(4): 2234-2247.

[11] Kurien C, Srivastava AK. Review on post-treatment emission control technique by application of diesel oxidation catalysis and diesel particulate filtration. Journal of Thermal Engineering 2019; 5(2): 108-118.

[12] Seong H, Choi S. Oxidation-derived maturing process of soot, dependent on $\mathrm{O} 2-\mathrm{NO} 2$ mixtures and temperatures. Carbon 2015; 93: 1068-1076. https://doi.org/10.1016/j.carbon.2015.07.008.

[13] Al-Maamary HMS, Kazem HA, Chaichan MT. Climate change: the game changer in the GCC region, Renewable and Sustainable Energy Reviews 2015; 76: 555-576, 2017. https://doi.org/10.1016/j.rser.2017.03.048.

[14] Kirchner U, Scheer V, Vogt R. FTIR spectroscopic investigation of the mechanism and kinetics of the heterogeneous reactions of NO2 and HNO3 with soot. J. Phys. Chem. 2000; 104: 8908-8915. https://doi.org/10.1021/jp0005322.

[15] Hoseini M, Yunesian M, Nabizadeh R, Yaghmaeian K, Ahmadkhaniha R, Rastkari N, Parmy S, Faridi S, Rafiee A, Naddafi K. Characterization and risk assessment of polycyclic aromatic hydrocarbons (PAHs) in urban atmospheric Particulate of Tehran, Iran. Environ Sci Pollut Res. 2015; 23(2): 1820-1832. DOI 10.1007/s11356-015-5355-0.

[16] Okuda T, Okamoto K, Tanaka S, Shen Z, Han Y, Huo Z. Measurement and source identification of polycyclic aromatic hydrocarbons (PAHs) in the aerosol in Xi'an, China, by using automated column chromatography and applying positive matrix factorization (PMF). Sci Total Environ. 2010; 408: 19091914. https://doi.org/10.1016/j.scitotenv.2010.01.040.

[17] Chaichan MT, Kazem HA, Abid TA. Traffic and outdoor air pollution levels near highways in Baghdad, Iraq. Environment, Development and Sustainability 2018; 20(2): 589-603. DOI: 10.1007/s10668-0169900-x.

[18] DeWinter JL, Brown SG, Seagram AF, Landsberg K, Eisinger DS. A national-scale review of air pollutant concentrations measured in the US near-road monitoring network during 2014 and 2015. Atmospheric Environment 2018; 183: 94-105. https://doi.org/10.1016/j.atmosenv.2018.04.003.

[19] Trasande L, Thurston GD. The role of air pollution in asthma and other pediatric morbidities. J Allergy Clin Immunol 2005; 115(4): 689-699. https://doi.org/10.1016/j.jaci.2005.01.056.

[20] Van Roosbroeck S, Hoek G, Meliefste K, Janssen NAH, Brunekreef B. Validity of residential traffic intensity as an estimate of long-term personal exposure to traffic-related air pollution among adults. Environ Sci. Technol. 2008; 42(4): 1337-1344. https://doi.org/10.1021/es0712827. 
[21] Bolaji BO, Olanipekun MU, Adekunle AA, Adeleke AE. An analysis of noise and its environmental burden on the example of Nigerian manufacturing companies. Journal of cleaner production 2018; 172 : 1800-1806. https://doi.org/10.1016/j.jclepro.2017.12.007.

[22] Owalska S, Davis MA. Noise-induced hearing loss. Noise Health 2012; 14: 274-280.

[23] WHO. World Health Organization: Burden of disease from environmental noise. Quantification of healthy life years lost in Europe. 2011. Available: 〈http://www.euro.who.int/en/healthtopics/environment-and-health/noise/publications).

[24] Karagöz Y. Emissions and performance characteristics of an SI engine with biogas fuel at different CO2 ratios. Journal of Thermal Engineering 2019; 5(6): 131-140.

[25] Chaichan MT. Performance and emissions characteristics of CIE using hydrogen, biodiesel, and massive EGR. International Journal of Hydrogen Energy (2018); 43: 5415-5435. https://doi.org/10.1016/j.ijhydene.2017.09.072.

[26] Chaichan MT, Kadhum AAH, Al-Amiery AA. Novel technique for enhancement of diesel fuel: Impact of aqueous alumina nano-fluid on engine's performance and emissions, Case Studies in Thermal Engineering (2017); 10: 611-620. https://doi.org/10.1016/j.csite.2017.11.006.

[27] Karagöz Y. Effect of hydrogen addition at different levels on emissions and performance of a diesel engine, Journal of Thermal Engineering 2018; 4(2): 1780-1790.

[28] Karagöz Y, Köten H. Effect of different levels of hydrogen + LPG addition on emissions and performance of a compression ignition engine. Journal of Thermal Engineering 2019; 5(2): 58-69.

[29] Joshi MP, Thipse SS. Combustion analysis of ci engine fuelled with algae biofuel blends, Journal of Thermal Engineering 2019; 5(6): 214-220.

[30] IRENA and CPI. Global Landscape of Renewable Energy Finance, International Renewable Energy Agency, Abu Dhabi, 2018. See also URL http://www.irena.org/publications/2018/Jan/Global-Landscapeof-Renewable-Energy-Finance.

[31] Chaichan MT, Kazem HA. Generating electricity using photovoltaic solar plants in Iraq. Springer, 2018. ISBN: 978-3-319-75030-9. https://doi.org/10.1007/978-3-319-75031-6.

[32] Al-Waeli AHA, Sopian K, Kazem HA, Chaichan MT. Nanofluid based grid connected PV/T systems in Malaysia: A techno-economical assessment, Sustainable Energy Technologies and Assessments 2018; 28: 81-95. https://doi.org/10.1016/j.seta.2018.06.017.

[33] Kazem HA, Chaichan MT. Effect of humidity on photovoltaic performance based on experimental study. International Journal of Applied Engineering Research (IJAER) 2015; 10(23): 43572-43577.

[34] Jiang Y, Lu L, Ferro AR, Ahmadi G. Analyzing wind cleaning process on the accumulated dust on solar photovoltaic (PV) modules on flat surfaces. Solar Energy 2018; 159: 1031-6. https://doi.org/10.1016/j.solener.2017.08.083.

[35] Kazem AA, Chaichan MT, Kazem HA. Effect of dust on photovoltaic utilization in Iraq: review article. $\begin{array}{lllll}\text { Renewable and } & \text { Sustainable Energy Reviews 2014; 37: }\end{array}$ https://doi.org/10.1016/j.rser.2014.05.073.

[36] Kazem HA, Al-Badi HAS, Al Busaidi AS, Chaichan MT. Optimum design and evaluation of hybrid solar/wind/diesel power system for Masirah Island. Environment, Development and Sustainability 2017; 19(5): 1761-1778. DOI: 10.1007/s10668-016-9828-1.

[37] Sultan M, Wu J, eAleem F, Imran M. Cost and energy analysis of a grid-tie solar system synchronized with utility and fossil fuel generation with major Issues for the attenuation of solar power in Pakistan. Solar Energy 2018; 174: 967-975. https://doi.org/10.1016/j.solener.2018.09.052.

[38] Chaichan MT. Combustion and emission characteristics of E85 and diesel blend in conventional diesel engine operating in PPCI mode. Thermal science and Engineering progress 2018; 7: 45-53. https://doi.org/10.1016/j.tsep.2018.04.013.

[39] Ekaab NS, Hamza NH, Chaichan MT. Performance and emitted pollutants assessment of diesel engine fueled with Biokerosene. Case Study in Thermal Engineering 2019; 13: 100381. https://doi.org/10.1016/j.csite.2018.100381. 